\title{
МОТИВАЦИОННО-ПОВЕДЕНЧЕСКИЙ КОМПОНЕНТ СТРАТЕГИИ УПРАВЛЕНИЯ САХАРНЫМ ДИАБЕТОМ 1 ТИПА У ДЕТЕЙ И ПОДРОСТКОВ
}

\author{
Е.Л. Сиделева, И.Ю. Черняк, И.М. Головенко \\ ГБУз «Детская краевая клиническая больнича», г. Краснодар
}

Учитывая неуклонный рост заболеваемости СД1 за последние годы, проблема мотивирования к удержанию активности по управлению СД1 сохраняет свою актуальность.

ЦЕЛЬ ИССЛЕДОВАНИЯ: изучить динамику изменения уровня отношения к заболеванию у детей, больных СД1, на фоне комплексного лечения с подключением психологического сопровождения и выработку копинг стратегий.

МАТЕРИАЛЫ И МЕТОДЫ: Под наблюдением находилось 65 детей (36 мальчиков (55\%) 29 девочек (45\%)) в возрасте 14-17 лет с СД1, длительностью заболевания от 6 месяцев до 5 лет. Испытуемые были разделены на 2 группы. Первую (контрольную) составили 35 человек, получавшие рассчитанную инсулинотерапию, диетотерапию, дозированные физические нагрузки. Во второй группе (основной), составившей 30 человек, базисное лечение было дополнено занятиями с психологом (4-6 индивидуальных занятий).

Для оценки уровня отношения к заболеванию нами был применен опросник «ТОБОЛ». В клинике хронических соматических заболеваний данная методика использует психодиагностический тест для оценки личностного реагирования на болезнь (12 типов отношения к болезни), эмоциональных переживаний, связанных с болезнью в период стационарного лечения и реабилитации больных. Мотивационно-поведенческий компонент отражает выработку определенной стратегии поведения в жизненных ситуациях в связи с болезнью (принятие «роли» больного, активное управление СД1, игнорирование заболевания « отрицание», пессимистические установки перевести на позитивные и пр.).

РЕЗУЛЬТАТЫ. Тестирование пациентов проводилось до начала и после окончания лечения. По данным повторного тестирования у детей основной группы занятия с психологом привели к значительному снижению негативного отношения к заболеванию у 76\% (23 ребенка) пациентов. В контрольной группе данный показатель снизился лишь у 31\% (11 человек) больных. Обращает на себя внимание позитивный настрой детей к жизни после занятий с психологом. «Гармоничный» тип реагирования наблюдался у 57\% (20 чел.) протестированных первой (контрольной) группы и у $80 \%$ (24 чел.) участников основной группы психологической коррекции, что свидетельствует о большей положительной динамике жизненной ориентации у подростков СД основной группы.

«Гармоничный» тип реагирования пациентов предполагает адекватную оценку своего состояния, активное участие в управлении заболеванием, комплаентность врача и пациентов и в то же время характеризуются стремлением преодолеть заболевание, неприятием «роли» больного, сохранением ценностной структуры и активного социального функционирования.

Выводы. Оценка уровня отношения к заболеванию у детей с СД1 определяет копинг-стратегию управления болезнью. Подключение психологического сопровождения к комплексному лечению СД1 у детей приводит к снижению уровня негативного отношения к заболеванию, что способствует стабилизации эмоционального статуса, улучшению компенсации заболевания, повышению качества жизни детей и активного социального функционирования. 